J. Clin. Chem. Clin. Biochem.

Vol. 26, 1988 , pp. $367-371$

(C) 1988 Walter de Gruyter \& Co.

Berlin - New York

\title{
Evidence for a Nonspecific Factor Interfering in the Radioimmunoassay of Somatoliberin-Like Immunoreactivity in Human Seminal Plasma
}

\author{
By M. Losa, G. Wolfram, J. Schopohl, S. Sobieszczyk ${ }^{1}$ ) and K. von Werder \\ Medizinische Klinik Innenstadt, University of Munich, Federal Republic of Germany
}

(Received July 27, 1987/February 15, 1988)

\begin{abstract}
Summary: In the present study we investigated the nature of somatoliberin-like immunoreactivity in human seminal plasma. In unextracted seminal plasma, somatoliberin-like immunoreactivity represented $3.8 \mu \mathrm{g} / \mathrm{l}$ somatoliberin, with a dilution curve that ran almost completely parallel to that of synthetic somatoliberin standard. After extraction by adsorption on hydrophobic C 18 Sep-pak cartridges or immunoaffinity chromatography, no somatoliberin-like immunoreactivity in seminal plasma could be detected. After gel permeation chromatography on a Sephadex G-50 fine column, all somatoliberin-like immunoreactivity of unextracted seminal plasma was recovered at the void volume of the column. When equal volumes of unextracted seminal plasma and radioiodinated somatoliberin were coincubated for two days at $4{ }^{\circ} \mathrm{C}$, gel chromatography revealed the disappearance of the normal $\left[{ }^{125} \mathrm{I}\right]$ somatoliberin peak, replaced by a new peak eluting shortly after the total volume of the column. When unextracted seminal plasma was heated at $90^{\circ} \mathrm{C}$ for $10 \mathrm{~min}$ or submitted to ultrafiltration, the interfering factor was no longer detectable. Our data show that enzymic degradation of radioiodinated somatoliberin led to misleadingly high concentrations of somatoliberin-like immunoreactivity in seminal plasma. These phenomena should therefore be considered when performing radioimmunoassays of short chain peptides in biological fluids.
\end{abstract}

\section{Introduction}

Somatoliberin was first isolated from two pancreatic islet cell tumours $(1,2)$, and subsequently from normal human hypothalamus (3). Using immunohistochemical and radioimmunoassay techniques, somatoliberin has been mainly localized in the infundibular region of the hypothalamus (4). Only picomol quantities of somatoliberin are present in the hypothalamus (4), but somatoliberin has also been detected in other areas of human brain and gut $(5,6)$. Occurrence at extrahypothalamic sites has also been reported for other known hypothalamic hypophysiotropic hormones (7). Moreover, most hypothalamic hormones have been shown to possess biological activities independent of pituitary regulation (8). Somatoliberin

\footnotetext{
') Present address: Department of Medicine, Section of Endocrinology, University of Chicago, Illinois, USA.
}

also has been found to stimulate enzyme secretion of the exocrine pancreas (9).

Peptide hormones have been found in seminal plasma of normal subjects (10), but the physiological significance of this finding is unknown. In the present study we investigated and characterized the presence of immunoreactive somatoliberin in human seminal plasma.

\section{Materials and Methods}

Seminal plasma

A pool of seminal plasma was obtained from the department of andrology of the University of Munich. Semen samples were collected into a plastic container by masturbation and were delivered to the laboratory within $2 \mathrm{~h}$. The pool of seminal plasma, obtained by mixing different specimens, was centrifuged at $1600 \mathrm{~g}$ for $10 \mathrm{~min}$ and the supernatant was aliquoted into $1 \mathrm{ml}$ plastic vials, which were stored at $-20^{\circ} \mathrm{C}$ until use. Semen sample aliquots were thawed at room temperature before recentrifugation at $1600 \mathrm{~g}$ for $10 \mathrm{~min}$ to remove cellular debris. 


\section{Somatoliberin radioimmunoassay}

Somatoliberin was measured using a specific antiserum raised in rabbits immunized with synthetic somatoliberin $1-44$ coupled to bovine thyroglobulin. This antibody is directed against the $C$-terminal region of somatoliberin and binds equally, on a equimolar basis, to somatoliberin 1-44, somatoliberin $1-40$, and somatoliberin $1-29$ (11). Somatoliberin was radioiodinated by the chloramine $T$ method and purified by a two step chromatographic procedure: The tracer was initially applied to a Sephadex G-10 column $(1 \times 10 \mathrm{~cm}$; Pharmacia, Uppsala, Sweden) and eluted in acetic acid $0.1 \mathrm{~mol} / 1+$ bovine serum albumin $1 \mathrm{~g} / \mathrm{l}$. The first peak, containing iodinated proteins, was collected and applied to a Sephadex G-50 fine column $(1 \times 56 \mathrm{~cm}$; Pharmacia, Uppsala, Sweden) and eluted with the same buffer as above. The descending part of the second peak, showing the highest binding to.somatoliberin antiserum, was pooled and diluted in radioimmunoassay buffer $\left(\mathrm{Na}_{2} \mathrm{HPO}_{4}\right.$ $0.063 \mathrm{~mol} / 1$ and $\mathrm{Na}_{2}$ EDTA $0.013 \mathrm{~mol} / \mathrm{l}$, pH 7.4, containing bovine serum albumin $1 \mathrm{~g} / \mathrm{l}, \mathrm{NaN}_{3} 0.2 \mathrm{~g} / \mathrm{l}$, Triton X-100 $1 \mathrm{ml} / \mathrm{l}$, and aprotinin (Trasylol ${ }^{\oplus}, 400000$ Kallikrein inhibitory units/l) at a concentration of about 5000 counts per minute. Somatoliberin tracer was stored frozen at $-20^{\circ} \mathrm{C}$ until use. Standards, diluted in radioimmunoassay buffer, or unknown samples $(0.1$ $\mathrm{ml}$ ) were incubated in polypropylene tubes with $0.1 \mathrm{ml}$ antiserum, diluted $1: 80000$ in radioimmunoassay buffer, for two days at $4^{\circ} \mathrm{C}$. After addition of somatoliberin tracer, containing $7 \mathrm{~g} / \mathrm{l}$ rabbit $\gamma$-globulins, incubation was continued for one day at $4{ }^{\circ} \mathrm{C}$. Antibody-bound and free somatoliberin were separated by a double antibody procedure, using $0.1 \mathrm{ml}$ goat antirabbit antiserum diluted $1: 60$ with radioimmunoassay buffer.

\section{Gel chromatography}

One-ml samples were separately applied to a Sephadex G-50 fine column $(1 \times 56 \mathrm{~cm})$, equilibrated, then eluted with radioimmunoassay buffer. Samples and calibration standards ${ }^{125} \mathrm{I}$, $\left[{ }^{125} \mathrm{I}\right]$ somatoliberin, and $\left[{ }^{125} \mathrm{I}\right]$ thyroglobulin) were eluted at $4{ }^{\circ} \mathrm{C}$ at a flow rate of $15 \mathrm{ml} / \mathrm{h}$. One-ml fractions were collected and kept frozen at $-20^{\circ} \mathrm{C}$ until assayed or, in case of radioiodinated substances, directly counted in a gamma-counter.

\section{Affinity chromatography of somatoliberin}

The $\gamma$-globulin fraction of antiserum K1783 was purified on a Protein-A Sepharose column (Pharmacia, Uppsala, Sweden). Absorbed $\gamma$-globulins were eluted with acetic acid $0.1 \mathrm{~mol} / \mathrm{l}$ and immediately desalted on a Sephadex G-25 column $(1 \times 12 \mathrm{~cm})$ equilibrated in Na-borate- $\mathrm{HCl} 0.01 \mathrm{~mol} / 1$ buffer, $\mathrm{pH} 8.7, \gamma-$ globulins were conjugated to $4 \mathrm{~B}-\mathrm{CNBr}$ activated Sepharose (Pharmacia, Uppsala, Sweden) following the -procedure suggested by the manufacturer. A $0.5 \times 1 \mathrm{~cm}$ column was prepared with the immunoadsorbent and equilibrated with radioimmunoassay buffer. Samples were diluted 3 -fold with radioimmunoassay buffer and successively applied to the immunoaffinity column. The column was washed with $10 \mathrm{ml}$ radioimmunoassay buffer and the antibody-bound somatoliberin was eluted with acetic acid $0.5 \mathrm{~mol} / \mathrm{l}$ containing bovine serum albumin $1 \mathrm{~g} / \mathrm{l}$. After lyophilization, samples were reconstituted with radioimmunoassay buffer before assay.

\section{Somatoliberin extraction}

The extraction method of Frohman et al. (12) was used with minor modifications. Briefly, $1 \mathrm{ml}$ of seminal plasma was diluted with $2 \mathrm{ml}$ trifluoroacetic acid $0.01 \mathrm{~mol} / 1$ and applied onto hydrophobic C 18 Sep-pak cartridges (Waters Associates, Millipore Corp., Milford, USA) previously activated by successive applications of trifluoroacetic acid $0.01 \mathrm{~mol} / \mathrm{l}$, acetonitrile (volume fraction 0.8 ) in trifluoroacetic acid $0.01 \mathrm{~mol} / \mathrm{l}$, and trifluoroacetic acid $0.01 \mathrm{~mol} / \mathrm{l}$ again. The column was then washed with $10 \mathrm{ml}$ trifluoroacetic acid $0.01 \mathrm{~mol} / \mathrm{l}$ and eluted with acetonitrile (volume fraction 0.8 ) in trifluoroacetic acid 0.01 $\mathrm{mol} / \mathrm{l}$. The eluate was lyophilized and then reconstituted in radioimmunoassay buffer before being assayed.

$$
: 1
$$

\section{Results}

The detection limit of the assay (defined as the smallest detectable concentration of ligand at 3 standard deviations from 0 hormone concentration) was $50-70 \mathrm{ng} / 1$ and $50 \%$ binding occurred at $400-500$ $\mathrm{ng} / \mathrm{l}$. Extraction of radioiodinated somatoliberin by affinity chromatography or adsorption onto Sep-pak C 18 cartridges yielded a mean recovery of 78.3 $\pm 3.5 \%$ and $87.1 \pm 2.3 \%$ ( $\pm S E)$, respectively. Unextracted seminal plasma contained $3.8 \mu \mathrm{g} / 1$ somatoliberin like-immunoreactivity at $50 \%$ binding of the standard curve. The dilution curve of unextracted seminal plasma ran parallel to the standard curve, though a slight deviation to the left occurred at the highest dilutions (fig. 1). However, no detectable amount of somatoliberin $(<50 \mathrm{ng} / \mathrm{l})$ was measured after extraction by affinity chromatography or adsorption onto C 18 Sep-pak cartridges. On the other hand, the somatoliberin immunoadsorbent column and the C 18 Sep-pak cartridge did not retain the somatoliberin-like immunoreactivity of seminal plasma, since after adsorption to the column and cartridge elevated levels of somatoliberin-like immunoreactivity could still be detected $(<2.5 \mu \mathrm{g} / \mathrm{l})$ in the effluent.

Following gel permeation chromatography, the somatoliberin-like immunoreactivity in seminal plasma did not coelute with somatoliberin standard and tracer, but appeared in the void volume of the column (fig. 2). Twenty-five $\mathrm{ng}$ somatoliberin $1-44$ in $0.5 \mathrm{ml}$

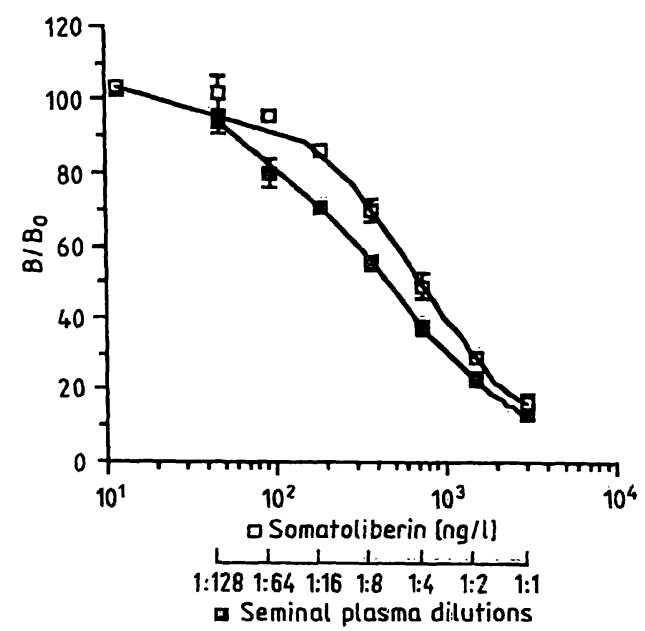

Fig. 1. Radioimmunoassay of unextracted seminal plasma. Dilution curves for synthetic somatoliberin $1-44(\square-\square)$ and unextracted seminal plasma $(\mathrm{a}-\mathbf{m})$ are shown. $\mathrm{B} / \mathrm{Bo}$, bound to maximum bound ratio. 


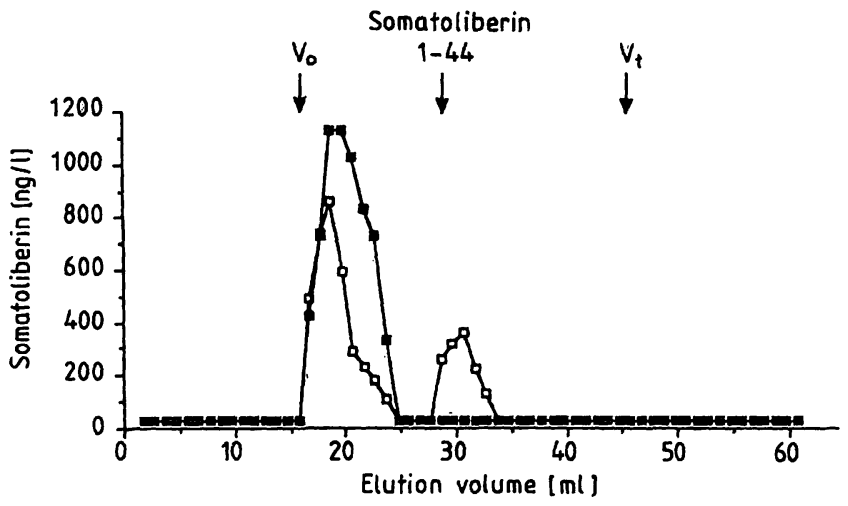

Fig. 2. Sephadex G-50 fine chromatography of unextracted seminal plasma $(\mathrm{a}-\mathbf{m})$ and of $25 \mathrm{ng}$ synthetic somatoliberin 1-44 ( $\square-\square)$ incubated at $4{ }^{\circ} \mathrm{C}$ for two days in $1 \mathrm{ml}$ unextracted seminal plasma. Samples were eluted with radioimmunoassay buffer. Aliquots of the $1 \mathrm{ml}$ fractions were assayed for somatoliberin by radioimmunoassay. The column void volume $\left(\mathrm{V}_{\mathrm{o}}\right)$, total volume $\left(V_{1}\right)$, and elution position of synthetic somatoliberin are indicated by the arrows.

radioimmunoassay buffer was incubated with $0.5 \mathrm{ml}$ unextracted seminal plasma at $4{ }^{\circ} \mathrm{C}$ for two days, in order to reproduce the conditions of our somatoliberin radioimmunoassay. At the end of the incubation period the mixture was chromatographed on the Sephadex G-50 column, then fractions were measured in radioimmunoassay. Control experiments for the recovery of somatoliberin standard following gel chromatography were performed by incubating $25 \mathrm{ng}$ somatoliberin stañdard in $1 \mathrm{ml}$ radioimmunoassay buffer for two days at $4{ }^{\circ} \mathrm{C}$ before chromatography, and $25 \mathrm{ng}$ somatoliberin standard in $0.5 \mathrm{ml}$ radioimmunoassay buffer mixed with $0.5 \mathrm{ml}$ séminal plasma just before gel permeation. As shown in figure 2 only a trace amount of somatoliberin standard was recovered in the position where somatoliberin standard eluted. Aside from a small peak near the void volume of the column, no other peak of somatoliberin-like immunoreactivity was found. The recovery of somatoliberin standard incubated in radioimmunoassay buffer alone was $88.5 \%$, whereas. after two days incubation in seminal plasma only $4.6 \%$ of added somatoliberin standard was recovered at the correct elution position; on the other hand, immediate chromatography, without incubation of somatoliberin standard mixed with seminal plasma, resulted in a minimal loss of recovered somatoliberin $(71.9 \%)$. The anomalous peak at the void volume of the column was still present.

To further investigate the nature of this nonspecific effect, somatoliberin tracer and unextracted seminal plasma were incubated together at $4{ }^{\circ} \mathrm{C}$ for two days.

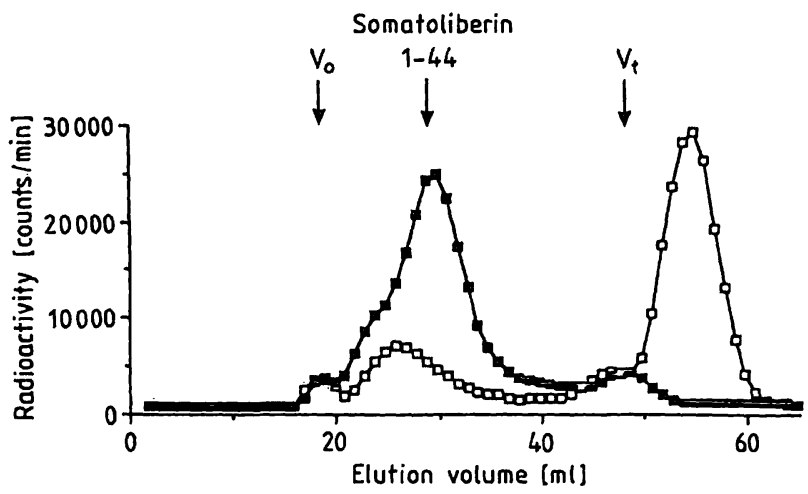

Fig. 3. Sephadex G-50 fine chromatography of $\left[{ }^{125} \mathrm{I}\right]$ somatoliberin after two days incubation at $4{ }^{\circ} \mathrm{C}$ with either unextracted seminal plasma $(\square-\square)$ or assay buffer $(\boldsymbol{\square}-\boldsymbol{\square})$. Samples were eluted with radioimmunoassay buffer. The $1 \mathrm{ml}$ fractions were directly counted in a gamma-counter. The column void volume $\left(\mathrm{V}_{\mathrm{o}}\right)$, total volume $\left(\mathrm{V}_{\mathrm{t}}\right)$, and elution position of synthetic somatoliberin are indicated by the arrows.

As shown in figure 3 , this procedure resulted in an almost complete degradation of labelled somatoliberin with generation of a new peak of radioactive material eluting shortly after the total volume of the column. Numerous attempts were made to eliminate this degradative enzymic activity, e.g. by addition of enzyme inhibitors to seminal plasma before incubation with labelled somatoliberin. Aprotinin, phenylmethylsulphonyl fluoride, and bacitracin did not, however, prevent somatoliberin tracer degradation.

Aliquots of unextracted seminal plasma were heated to $90^{\circ} \mathrm{C}$ for $10 \mathrm{~min}$, centrifuged to remove precipitated proteins, and subsequently measured in radioimmunoassay or incubated with labelled somatoliberin. Heat treatment reduced dramatically the amount of somatoliberin-like immunoreactivity of seminal plasma $(0.8 \mu \mathrm{g} / \mathrm{l})$. Moreover, somatoliberin tracer was not degraded by coincubation with heated seminal plasma, as shown in figure 4. No radioactive peak eluted after the normal somatoliberin peak; however, another anomalous peak appeared near the void volume of the column (fig. 4), probably due to nonspecific binding of somatoliberin tracer to denatured proteins. This suggestion was supported by the finding that prior ultrafiltration of the heated seminal plasma, using Centrisart I (Sartorius GmbH, Göttingen, Federal Republic of Germany; exclusion limit: $M_{\mathrm{r}}$ $=10000-15000$ ), led to disappearance of the first peak of radioactivity (fig. 4). Ultrafiltered seminal plasma contained no detectable amount $(<50 \mathrm{ng} / \mathrm{l})$ of somatoliberin-like immunoreactivity by radioimmunoassay. 


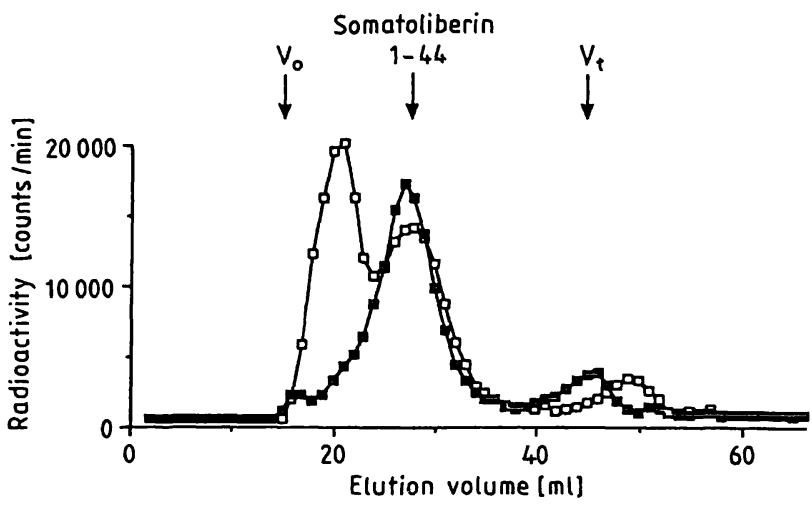

Fig. 4. Sephadex G-50 fine chromatography of $\left[{ }^{125} \mathrm{I}\right]$ somatoliberin after two days incubation at $4^{\circ} \mathrm{C}$ with either unextracted seminal plasma heated at $90^{\circ} \mathrm{C}$ for $10 \mathrm{~min}(\square-\square)$ or unextracted seminal plasma heated at $90^{\circ} \mathrm{C}$ for $10 \mathrm{~min}$ and subsequently ultrafiltrated $(\square-\square)$. Samples were eluted with radioimmunoassay buffer. The $1 \mathrm{ml}$ fractions were directly counted in a gamma-counter. The column void volume $\left(\mathrm{V}_{\mathrm{o}}\right)$, total volume $\left(V_{t}\right)$, and elution position of synthetic somatoliberin are indicated by the arrows.

\section{Discussion}

Using a highly specific antibody and purified radioiodinated somatoliberin, we developed a radioimmunoassay system able to detect $50-70 \mathrm{ng} / \mathrm{l}$ somatoliberin. When unextracted seminal plasma was assayed, high somatoliberin levels were found and dilution curves of synthetic somatoliberin and unextracted seminal plasma ran almost completely parallel (fig. 1). However, we found that extraction of seminal plasma by affinity chromatography or adsorption onto C 18 Sep-pak cartridges led to disappearance of somatoliberin-like immunoreactivity from seminal plasma, whereas such immunoreactivity was still present in the effluent after the adsorption step. The chromatographic profile of seminal plasma demonstrated the presence of a major peak of somatoliberinlike immunoreactivity near the void volume of the Sephadex G-50 fine column and the complete disappearance of immunoreactivity from the elution position of somatoliberin standard (fig. 2). This peak near the void volume of the column might be due to aggregation forms of somatoliberin (at least 4-6 molecules, in view of the exclusion limit of the Sephadex column), adsorption of somatoliberin onto seminal plasma proteins, or elution of degrading enzyme(s), which in the somatoliberin radioimmunoassay could cause destruction of the tracer, leading to a misleadingly high somatoliberin concentration. The latter hypothesis is supported by the experiment shown in figure 3. Incubation of seminal plasma with somatoliberin tracer led to an almost complete disappearance of the peak at the void volume of the column, thus excluding aggregation of radiolabelled somatoliberin molecules or their binding to native seminal plasma proteins; it also resulted in the appearance of nearly all radioactive material shortly after the total volume of the column, as if labelled somatoliberin were completely destroyed by an enzymic degrading activity present in seminal plasma. Elution of small fragments of somatoliberin shortly after the total volume of the column, though uncommon, is not inkown. Similar effects have been reported for other peptides. They seem to be due to interaction of the fragments with the column packing material $(13,14)$. These results demonstrate the non-identity of somatoliberin standard with the somatoliberin-like immunoreactivity of seminal plasma. This fact underscores the notion that parallelism between standard and "unknown" in a radioimmunoassay system is a prerequisite, but it is not sufficient to validate the method.

Degradation of hypothalamic hormones by peptidases in rat and human serum has already been reported (15) and has been postulated to cause high "blank effects" in one radioimmunoassay for somatostatin (16). Nevertheless, enzymic degradation of the tracer is probably an underrestimated problem in validating a radioimmunoassay system (17).

Rafferty \& Schulster (18) found the same degradation of labelled somatoliberin after overnight incubation with rat plasma. However, using a Sephadex G-50 column, they found that the smaller radiolabelled component(s) eluted before the total volume of the column. This discrepancy with our results can be best explained, apart from differences in the methodology, by the different somatoliberin preparation used in the two studies, namely somatoliberin $1-40$ in Rafferty \& Schulster study (18) and somatoliberin 1-44 in ours. Confirming previous results (18), we were also unable to prevent somatoliberin tracer degradation by addition of effective concentrations of protease inhibitors like aprotinin, phenylmethylsulphonyl fluoride, and bacitracin. However, heating seminal plasma to $90^{\circ} \mathrm{C}$ for $10 \mathrm{~min}$ resulted in loss of the degradative enzymic activity of seminal plasma. The appearance of another peak of radioactivity near the void volume of the column is probably due to nonspecific adsorption of somatoliberin tracer to denatured proteins produced by the heating procedure. This suggestion is supported by the fact that when labelled somatoliberin is incubated with heated and subsequently ultrafiltered seminal plasma, gel permeation chromatography shows only one peak of radioactivity coeluting with somatoliberin standard. Moreover, somatoliberin measurement in heated sem- 
inal plasma demonstrated a dramatic reduction of somatoliberin-likc immunoreactivity. The minimal residual somatoliberin activity is very probably due to nonspecific binding of somatoliberin to denatured proteins and not to residual degradative enzymic activity. Very recently, Frohman and coworkers (19) described the rapid enzymic degradation of somatoliberin to a biologically inactive product by plasma both "in vivo" and "in vitro" consisting of the removal of two amino acids from the $\mathrm{NH}_{2}$-terminus. The enzyme(s) responsible has not yet been identified, though a dipeptidylaminopeptidase has been suggested (19). It is tempting to speculate that the same degradative enzymic activity is present in seminal plasma; since the first amino acid of somatoliberin is tyrosine, a radioiodinated dipeptide should elute near the total volume of the Sephadex G-50 column. However, somatoliberin contains a second tyrosine residue at position 7. If, therefore, the cleavage of the two first amino acids at the $\mathrm{NH}_{2}$-terminus were the only enzymic degrading activity of seminal plasma, we should observe a second peak of radioactivity coeluting near the intact somatoliberin standard and corresponding to labelled somatoliberin 3-44. It seems likely that degradation of somatoliberin by seminal plasma is more complete and probably leads to production of different small fragments.

In conclusion, our study demonstrates that somatoliberin-like immunoreactivity in seminal plasma is an artifact due to degradative enzymic activity, which is able to destroy radiolabelled and, probably, native somatoliberin. It is suggested that coincubation studies of labelled substances and organic fluids must be performed in order to reveal tracer degradation as a source of misleading results in radioimmunoassays.

\section{References}

1. Guillemin, R., Brazeau, P., Bohlen, P. E., Esch, F., Ling, N. \& Wehrenberg. W. (1982) Science 218, 585- 587.

2. Rivier, J., Spiess, J., Thorner, M. O. \& Vale, W. (1982) Nature 300, 276-278.

3. Ling, N., Esch, F., Bohlen, P., Brazeau, P., Wehrenberg, W. \& Guillemin, R. (1984) Proc. Natl. Acad. Sci. USA 81 , $4302-4306$.

4. Leidy, J. W. Jr. \& Robbins, R. J. (1986) J. Clin. Endocrinol. Metab. 62, 372-378

5. Bloch, B., Brazeau, P., Ling, N., Bohlen, P., Esch, F., Wehrenberg, W., Benoit, R., Bloom, F. \& Guillemin, R. (1983) Nature 301, 607-608.

6. Christofides, N. D., Stephanon, A., Suzuki, H., Xiangon, Y. \& Bloom, S. R. (1984) J. Clin. Endocrinol. Metab. 59, $747-751$.

7. Pearse, A. G. (1976) Nature 262, 992-998.

8. Krieger, D. T. (1983) Science 222, 975-985.

9. Pindol, S. J., Seifert, H., Thomas, M. W., Rivier, J. \& Vale, W. (1984) Science 225, 326-328.

10. Sharp, B. \& Pekary, E. (1981) J. Clin. Endocrinol. Metab. $52,586-588$.

11. Stalla, G. K., Losa, M., Kaliebc, T., Stalla, J., Schopohl, J., Muller, O. A. \& von Werder, K. (1987) In: Growth hormone, growth factors, and acromegaly (Ludecke, D. K. \& Tolis, G., eds.), pp. 165-179, Raven Press, Ncw York.

12. Frohman, L. A., Thominet, J. L., Webb, C. B., Vance, $M$. L., Uderman, H., Rivier, J., Valc, W. \& Thorner, M. O. (1984) J. Clin. Invest. 73, 1304-1311.

13. Savage, C. R. Jr. \& Cohen, S. (1972) J. Biol. Chem. 247, $7609-7615$.

14. Kasson, B. G. \& Hsueh, A. J. W. (1986) Endocrinology $118,23-31$.

15. Benuck, M. \& Marks, N. (1976) Lifc Sci. 19, 1271- 1276.

16. Patel, Y. C., Wheatley, T., Fitz-Patrick, D. \& Brock, G. (1980) Endocrinology 107, 306-313.

17. Rorstad, O. P. (1983) In: Brain Peptides (Kricger, D. T. \& Brownstein, M., eds.), pp. 465-483, John Wilcy \& Sons, New York.

18. Rafferty, B. \& Schulster, D. (1985) Mol. Cell. Endocrinol. $41,19-25$.

19. Frohman, L. A., Downs, T. R., Williams, T. C., Heimer, E. P., Pan, X. C. E. \& Felix, A. M. (1986) J. Clin. Invest. 78, 906-913.

Dr. Klaus von Werder

Medizinische Klinik Innenstadt

Universitäl München

Ziemssenstr. 1

D-8000 München 2 
